\title{
DETECTING SPORTING TALENTS WITH Z-STRATEGY - CROSS SECTIONAL STUDY
}

\author{
DETECÇÃO DE TALENTOS ESPORTIVOS COM A ESTRATÉGIAZ-ESTUDO TRANSVERSAL \\ DETECCIÓN DE TALENTOS DEPORTIVOS CON LA ESTRATEGIAZ-ESTUDIO TRANSVERSAL
}

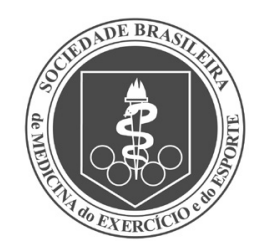

Original Article

Artigo Original

Artículo Original

\author{
Josivaldo de Souza-Lima' (iD \\ (Physical Education Professional) \\ Jaime Leppe Zamora² (DD \\ (Kinesiologist) \\ Rodrigo Yáñez-Sepúlveda ${ }^{3}$ (D) \\ (Physical Education Professional) \\ Victor Keihan Rodrigues Matsudo' (ID) \\ (Fisician) \\ Sandra Mahecha-Matsudo 4 (ID) \\ (Fisician) \\ 1. Centro de Estudos do Laboratório \\ de Aptidão Física de São Caetano \\ do Sul, SP, Brazil. \\ 2. Universidad del Desarrollo, \\ Faculty of Medicine Clínica \\ Alemana, Santiago, Chile. \\ 3. Pontificia Universidad Católica \\ de Valparaíso, Faculty of Philosophy \\ and Education, Chile. \\ 4. Universidad Mayor, Faculty of \\ Sciences, Santiago, Chile.
}

\section{Correspondence:}

Sandra Marcela Mahecha Matsudo José Toribio Medina, 29, Estación Central, Santiago, Chile. 8340589 sandra.mahecha@umayor.cl

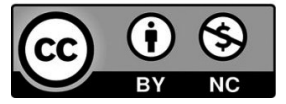

\section{ABSTRACT}

Introduction: Due to the relationship between early identification of physical and anthropometric characteristics above the population mean in children and adolescents, and success in sports, detecting potential sports talents should be broadly and systematically used as a strategy for the early identification of physical characteristics favorable to the sport in question. However, most studies do not use representative samples, or else they present talent detection without using valid scientific methods. This retrospective, comparative study therefore presents the identification of potential sports talents using the Z Strategy, calculated with anthropometric, neuromotor and physical fitness data. Objective:To identify physical abilities and anthropometric values above what are considered the normal ranges in a population of students in the 8th year of basic education, in Chile. Methods: The sample consisted of 9,429 students from public and private schools (50.9\% boys). Data were obtained from a cross-sectional study conducted in 2013. Physical fitness and anthropometric data were recompiled through the Educational Quality Measurement System (Sistema de Medición de la Calidad de Educación - SIMCE) of physical education. The "Z Strategy" was used to detect sports talents by identifying values above the population mean. Results: In at least one variable, a total of 619 male and 623 female students with a standard deviation $\geq 2$ (Z2) were detected. Conclusion: "Z Strategy" was able to detect sports talents of both sexes and of different ages. Level of evidence III; Retrospective comparative study.

Keywords: Talent; Sports; Physical fitness; School; Children.

\section{RESUMO}

Introdução: Devido à relação entre a identificação precoce das características físicas e antropométricas acima da média populacional em crianças e adolescentes e o êxito nos esportes, a detecção de potenciais talentos esportivos deve ser feita de forma ampla e sistemática como estratégia para a identificação precoce das características físicas favoráveis para o esporte em questão. Entretanto, a maioria dos estudos não utiliza amostras representativas, ou apresenta a detecção de talentos sem a utilização de métodos científicos válidos. O presente estudo comparativo retrospectivo, portanto, apresenta a identificação de potenciais talentos esportivos utilizando a estratégia $Z$, calculada com os dados das variáveis antropométricas, neuromotoras e de aptidão física. Objetivo: Identificar as habilidades físicas e os valores antropométricos acima dos níveis considerados normais em uma população de alunos do $8^{\circ}$ ano de Educação Básica no Chile. Métodos: A amostra foi composta por 9.429 estudantes de escolas públicas e particulares (50,9\% sexo masculino). Os dados foram obtidos a partir de um estudo transversal realizado em 2013. Os dados antropométricos e de aptidão física foram recopilados através do Sistema de Medición de la Calidad de Educación - SIMCE de educação física. A "Estratégia Z" foi utilizada para detectar os talentos esportivos ao identificar os valores acima da média da população. Resultados: Em, pelo menos, uma variável, um total de 619 alunos e 623 alunas com um desvio padrão de $\geq 2$ (Z2) foi detectado. Conclusão: A "Estratégia-Z" foi capaz de detectar talentos esportivos de ambos os sexos e em diferentes idades. Nível de evidência III; Estudo retrospectivo comparativo.

Descritores: Talento; Esportes; Aptidão física; Escola; Criança.

\section{RESUMEN}

Introducción: Debido a la relación entre la identificación precoz de las características físicas y antropométricas por encima del promedio poblacional en niños y adolescentes y el éxito en los deportes, la detección de potenciales talentos deportivos debe ser hecha de manera amplia y sistemática como estrategia para la identificación precoz de las características físicas favorables para el deporte en cuestión. Entretanto, la mayoría de los estudios no utiliza muestras representativas, o presenta la detección de talentos sin el uso de métodos científicos válidos. El presente estudio comparativo retrospectivo, por lo tanto, presenta la identificación de potenciales talentos deportivos utilizando la estrategia Z, calculada con los datos de las variables antropométricas, neuromotoras y de aptitud física. Objetivo: Identificar las habilidades físicas y los valores antropométricos por encima de los niveles considerados normales en una población de alumnos de $8^{\circ}$ año de Educación Básica en Chile. Métodos: La muestra fue compuesta por 9429 estudiantes de escuelas públicas y privadas (50,9\% sexo masculino). Los datos se obtuvieron a partir de un estudio transversal realizado en 2013. Los datos antropométricos y de aptitud física fueron recopilados a través del Sistema 
de Medición de la Calidad de Educación - SIMCE de educación física. La "Estrategia Z" fue utilizada para detectar los talentos deportivos al identificar los valores por encima del promedio de la población. Resultados: Se detectó en por lo menos una variable, un total de 619 alumnos y 623 alumnas con una desviación estándar de $\geq 2$ (Z2). Conclusión: La "Estrategia-Z" fue capaz de detectar talentos deportivos de ambos sexos y en diferentes edades. Nivel de evidencia III;

\section{Estudio retrospectivo comparativo.}

Descriptores: Talento; Deportes; Aptitud física; Escuela; Niños.

\section{INTRODUCTION}

Identifying values and patterns of variables off the upper limits considered normal for a population, can be a useful strategy for determining a potential talent for a determined task, such as mental, manual and/or physical. ${ }^{1,2}$ In sport this strategy is used for Search - Detection - of individuals that present physical and anthropometric parameters, that may help the recognition of individuals with potential sports aptitudes. These individuals exhibit parameters very different from the mean population; these parameters are considered as a strategy for a scientific detection of sporting talents, thus supporting the selection and the promotion for high-performance sport. ${ }^{3}$

In Chile, the identification occurs after the individual is already inside a sports club. At this moment only the sport performance is considered, but not the important variables such as biological maturation. ${ }^{4}$

On many occasions, especially in less developed countries, the talent detection program happens in an unsystematic way, where the search for sports talent is done in an irregular way. In this case, it is the state, the company, the club or the family itself that seeks to cover the required conditions. In this system, the discovery of a national or international talent is mostly a matter of hazard and fortuitous genetic combination. ${ }^{5}$

The current way to select Chilean athletes to build up the High Yield program is through selective sports. These selections are performed when there are some sporting events such as: School Pre-School Games, School Sports Games, Higher Education Sports Leagues, South American School Games, Andean Integration Games and National Sports Games. ${ }^{6}$ However, this form of selection does not cover the principle of early detection, therefore it also does not offer to a potential athlete all the possibilities of physical fitness development, in the right timing to become of excellence?

Another principle that is left aside, is the proper use of all the measures, aiming for the detection, --in a sufficient number--, of people (mainly children and adolescents) that possess favorable characteristics for admission in a basic training program. ${ }^{8-10}$

In this context, in Brazil it was proposed a method for the detection of sports talents in a population in 1985, named as strategy Z, that was proposed to identify highlighted physical fitness values available in the population data.

For instance, when we identify for a determined parameter, a Z value equal to 1, meaning that this individual is plus-one standard deviation above the population mean. In demographic terms, this is interpreted as an $84.13 \%$ of better performance in the specific parameter, regarding the population of the same age and sex. This interpretation is determined through a Gaussian distribution, by the following calculation:

\section{$\mathrm{X} 1-\mathrm{X} 2 / \mathrm{SD} 2=\mathrm{Z}($ ?) equation 1 .}

Where:
- $X_{1}$ = group mean individual
-X2 = population mean, and
- $\mathrm{SD} 2=$ population standard deviation

One of the advantages of using this calculation is the easy visualization in the graph (Figure 1) "Aptidogram", where all physical and anthropometric variables are presented in units of standard deviation.

The objective of our study was to identify a population of students, children and adolescents that presented anthropometric, neuromotor and physical fitness values, over the mean population values. We characterize this group as potential sports talents.

In this study, we use the database of the System of Measurement of the Quality of Physical Education (SIMCE-EF, abbreviated acronym in Spanish) and apply the statistic parameter known as strategy $Z^{11,12}$. Finally, we propose a scientific systematization aiming to an early detection of sporting talents in Chile, to overcome the actual scenario of dearth of resources to carry out new research lines at a national level.

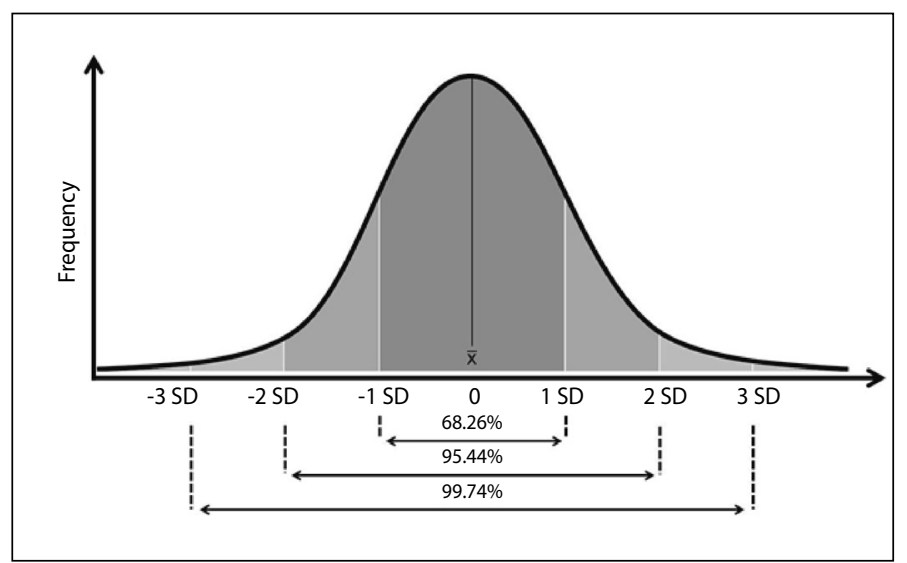

Figure 1. Standard deviation distribution model according to Z strategy (Matsudo, 1985)

\section{MATERIALS AND METHODS}

Cross-sectional study with a nationally representative sample. The sample was obtained through the evaluation of the physical fitness of schoolchildren of public and private schools of all 15 regions of the country, chosen by statistical sampling. Students from 401 schools were evaluated, where the sample consisted in children and teenagers of both sexes from the 8th grade of primary education were assessed.

All subjects were invited to participate in the study voluntarily and expressed their agreement, and the informed consent form was signed by their parents or guardians

From a total sample of 30,660 children and adolescents (15,545 girls, 15,115 boys) a subsample of 11,981 participants was selected, who were tested for their physical fitness. It was assessed anthropometric measures, such as weight (kilograms), height (centimeters) and waist circumference (centimeters). In addition, it was assessed the physical fitness, as follows: i) 20-meter Shuttle Run test (i.e., indirect $\mathrm{VO}_{2} M a x$ predictive test); ii) the Cafra test (i.e., cardiorespiratory endurance 2 test); iii) sit-and-reach test (i.e., flexibility); iv) the arm flexion test (for upper limb strength); v) the horizontal jump test (for lower limb strength); and vi) the short abdominal test (i.e., abdominal strength). For everyone, a z-index was generated, which determined its position in relation to the population mean in units of standard 
deviation. The National Physical Education Survey was authorized under the Chilean Law of Sport (ethics protocol approval number) 19.712, article 5.

Data analysis was performed by comparing their results with the reference standard (absolute) values, percentage difference, and afterwards, by determining the position in relation to the population mean in standard deviation units.

\section{Statistical analysis}

The database was built in Excel software, whilst the statistical analysis was performed with Stata statistical package, version 9. When analyzing the data, we verified that the initial database had no control over the data entry. During the revision of the data, we identified several outliers, mostly because of mistyping during the recollection process. The difference between sex, was assessed by test t student and the significance level adopted was $p<0.05$.

Body mass index was determined by age and gender. When BMI percentile was over p95 ( $n=1663$ ) and below p5 ( $n=103)$, individuals were considered as outliers, based on the table provided by the WHO for Chilean population. In addition, 786 individuals were eliminated, since neither their weight nor height were registered. Thus, the final sample of the database used for the calculation of strategy $Z$ was of 9,429 students from both sexes.

$$
\mathrm{Z}=\frac{x-\mathrm{u}}{\mu}
$$

\section{RESULTS}

Among the 9,429, aged from 13 to 16 years, 619 were detected with $(Z \geq 2)$ in at least one physical or anthropometric variable in boys, representing $12.9 \%$ of the boy population, as well as 613 with $(Z \geq 2)$ in the girl sex, which represents $13.5 \%$ of the girl population.

The results found in our research show a high proportion of adolescents who presented high values related to parameters of physical capacity, being these elementary to the sport conquest. In this sense, we want to highlight some fundamental physical characteristics for sports performance.

We will highlight here the main physical characteristics with a high-frequency Z value higher than 2, that is, characteristics that are found in less than $5 \%$ of the population, according to the theoretical model presented in Figure 1.

The first characteristic we highlight is the strength of upper limbs (Arm Flexion) and lower limbs (Horizontal Jump). Muscle strength is currently considered the main physical characteristic because, from the development of optimal strength, other physical qualities are better developed such as the power and speed of execution of different sporting gestures. Boyle M. in 2010 describes that muscle strength is essential to allow an improvement in the desired movement pattern. ${ }^{13}$

In addition to the physical stature, also here presenting a high frequency and considered fundamental in collective sports like basketball, volleyball and in individual sports like athletics, we also emphasize the essential flexibility in sports that require great amplitudes of movements like Olympic gymnastics, being able to be so much artistic and acrobatic.

Another fundamental quality is the maximum oxygen consumption (VO2max). In this study, 49 adolescents of both sexes who had a Z superior to 2 of Vo2max were identified, the probability of identifying subjects with this value is less than $5 \%$ in a population, thus highlighting the importance of using science in a systematic way with basic criteria to identify potential natural born talents. It is important to emphasize that VO2max is an essential biological determinant for most endurance sports and at the same time an indicator of the athlete's physical capacity. ${ }^{14}$

Figure 2, the procedures used for inclusion and exclusion criteria to determine the final sample for this investigation are shown. Briefly, we used the sub-sample from the total SIMCE-EF database, including only those individuals with all the information registered. As aforementioned, individuals considered as outliers were excluded.

Table 1 shows the proportions of individuals according to age and sex. In the boy sex, 53.9\% of the sample was 14 years old, as well as in the girl sex, which presented a proportion of $56.4 \%$ at the same age.

Table 2 shows the averages and standard deviations of physical fitness and anthropometric variables of students who were part of the final sample of the study. There was a significant difference in

Table 1. General characteristics of the sample.

\begin{tabular}{c|c|c|c|c}
\hline Characteristics & \multicolumn{2}{|c|}{ Boy $\left(\mathbf{n}^{\circ}=\mathbf{4 8 0 2}\right)$} & \multicolumn{2}{c}{ Girl $\left(\mathbf{n}^{\circ}=\mathbf{4 6 2 7}\right)$} \\
\hline Total & $\mathbf{n}^{\circ}$ & $\%$ & $\mathbf{n}^{\circ}$ & $\%$ \\
\hline Age & & & & \\
\hline 13 & 1,403 & 29.2 & 1,530 & 33.1 \\
\hline 14 & 2,589 & 53.9 & 2,611 & 56.4 \\
\hline 15 & 628 & 13.1 & 384 & 8.3 \\
\hline 16 & 182 & 3.8 & 102 & 2.2 \\
\hline Total & 4,802 & 100.0 & 4,627 & 100.0 \\
\hline
\end{tabular}

Distribution according to the age of primary school children, Chile 2013.

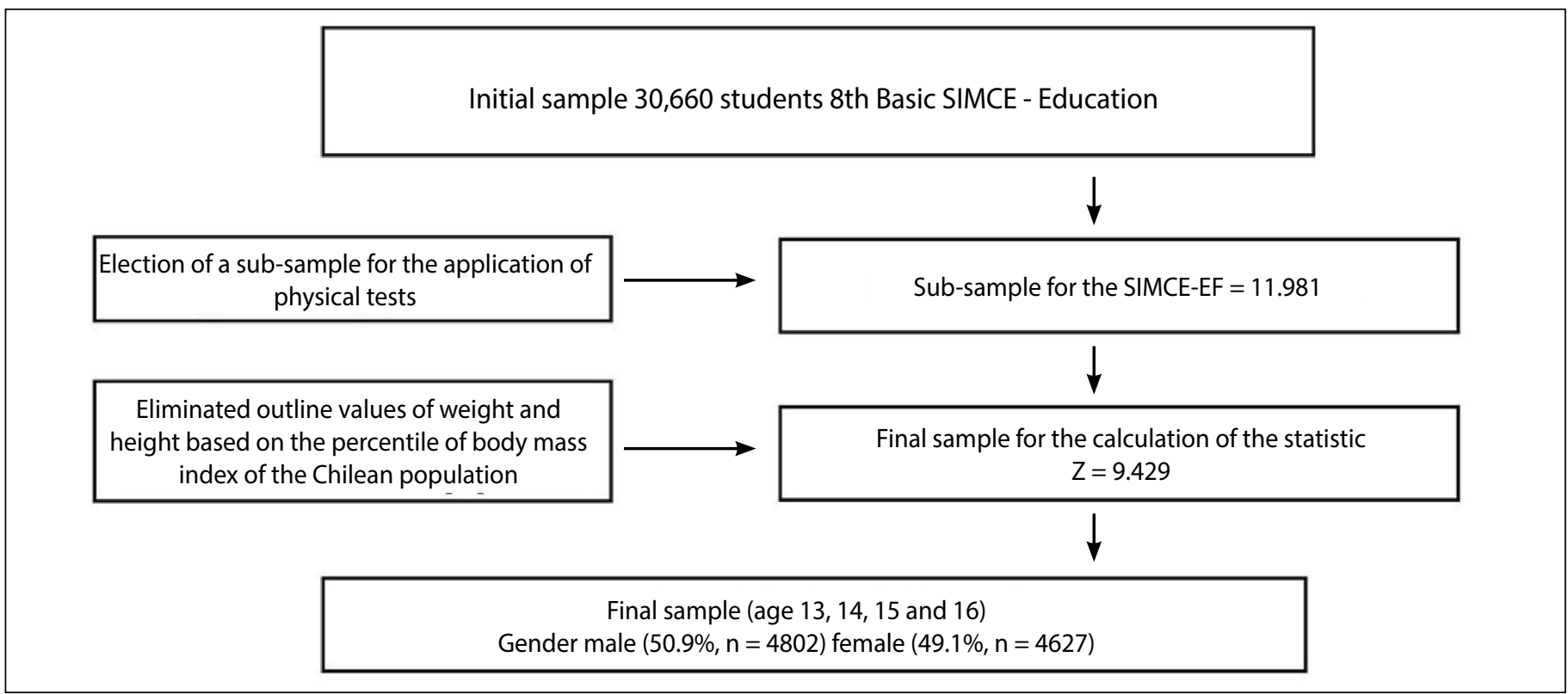

Figure 2. Sample eligibility process. 
Table 2. Descriptive values of physical fitness and anthropometric measures according to the age of primary school children, Chile 2013.

\begin{tabular}{|c|c|c|c|c|c|}
\hline \multirow{2}{*}{$\frac{\text { Age (years) }}{\text { Test and Measurements }}$} & \multicolumn{2}{|c|}{ Boy $\left(n^{\circ}=4802\right)$} & \multicolumn{2}{|c|}{$\operatorname{Girl}\left(n^{\circ}=4627\right)$} & \multirow[t]{2}{*}{ Value $p$} \\
\hline & Mean & SD & Mean & SD & \\
\hline \multicolumn{6}{|l|}{ Height (cm) } \\
\hline 13 & 162.81 & 7.81 & 156.78 & 6.06 & 8.47 \\
\hline 14 & 164.62 & 7.40 & 157.34 & 5.86 & 2.56 \\
\hline 15 & 165.71 & 7.11 & 157.42 & 5.87 & 3.39 \\
\hline 16 & 166.10 & 7.75 & 156.64 & 6.00 & 1.58 \\
\hline \multicolumn{6}{|l|}{ Weight (kg) } \\
\hline 13 & 55.39 & 8.64 & 53.47 & 7.58 & 1.53 \\
\hline 14 & 57.13 & 8.83 & 54.50 & 7.96 & 2.26 \\
\hline 15 & 58.75 & 8.62 & 56.21 & 8.25 & 4.12 \\
\hline 16 & $60.44^{*}$ & 9.47 & 56.18 & 7.85 & 0.00 \\
\hline \multicolumn{6}{|l|}{ Waist circumference $(\mathrm{cm})$} \\
\hline 13 & 71.92 & 7.70 & 69.75 & 7.64 & 3.66 \\
\hline 14 & 72.13 & 7.86 & 70.18 & 7.93 & 9.32 \\
\hline 15 & 73.15 & 7.52 & 72.20 & 8.38 & 0.06 \\
\hline 16 & $74.60^{*}$ & 8.01 & 72.42 & 7.41 & 0.02 \\
\hline \multicolumn{6}{|l|}{ Flexibility (cm) } \\
\hline 13 & 24.45 & 9.42 & 29.49 & 11.27 & 5.38 \\
\hline 14 & 25.19 & 10.26 & 29.46 & 11.49 & 1.18 \\
\hline 15 & 26.65 & 9.78 & $28.46^{*}$ & 11.49 & 0.00 \\
\hline 16 & 26.78 & 10.71 & 28.03 & 11.63 & 0.35 \\
\hline \multicolumn{6}{|l|}{ Horizontal jump (cm) } \\
\hline 13 & 153.31 & 30.02 & 121.58 & 26.16 & 1.43 \\
\hline 14 & $160.75^{*}$ & 31.77 & 124.95 & 26.59 & 0.00 \\
\hline 15 & 168.46 & 30.63 & 177.34 & 27.24 & 2.09 \\
\hline 16 & 170.10 & 34.29 & 116.27 & 27.26 & 1.64 \\
\hline \multicolumn{6}{|l|}{ Arm flexion (rep) } \\
\hline 13 & 12.72 & 9.64 & 12.81 & 8.40 & 0.78 \\
\hline 14 & 14.55 & 10.07 & 12.97 & 8.65 & 1.27 \\
\hline 15 & 15.55 & 10.57 & 12.68 & 8.93 & 9.47 \\
\hline 16 & 16.57 & 10.89 & 10.99 & 8.21 & 9.91 \\
\hline \multicolumn{6}{|l|}{ Abdominal strength (rep) } \\
\hline 13 & 21.79 & 6.97 & 19.36 & 8.52 & 4.02 \\
\hline 14 & 21.94 & 6.96 & 19.49 & 8.54 & 2.26 \\
\hline 15 & 21.78 & 6.88 & 17.61 & 9.26 & 8.72 \\
\hline 16 & $21.23^{*}$ & 7.55 & 19.01 & 8.44 & 0.02 \\
\hline \multicolumn{6}{|l|}{ Cafra test (fc) } \\
\hline 13 & 119.28 & 26.11 & 133.78 & 27.33 & 5.48 \\
\hline 14 & 118.06 & 25.67 & 134.38 & 27.47 & 2.03 \\
\hline 15 & 112.14 & 26.12 & 131.62 & 28.22 & 6.64 \\
\hline 16 & $113.64^{*}$ & 26.29 & 123.89 & 28.05 & 0.00 \\
\hline \multicolumn{6}{|l|}{ Vo2Max (Navette test) } \\
\hline 13 & 47.03 & 5.90 & 40.89 & 5.47 & 1.03 \\
\hline 14 & 46.58 & 6.07 & 39.45 & 5.70 & 9.01 \\
\hline 15 & 46.79 & 6.67 & 37.25 & 6.58 & 1.40 \\
\hline 16 & 45.83 & 6.73 & 35.97 & 6.15 & 6.68 \\
\hline
\end{tabular}

* Statistical differences between the sexes; Significance adopted $p<0.05 .{ }^{*}$ Student $t$ test for independent sample. body weight at the age of 16 years, with a higher boy weight, as well as greater waist circumference, greater abdominal strength and lower heart rate in the Cafra test. At the age of 14, the boy presented greater horizontal impulsion. Girls presented greater flexibility only at the age of 15 years.

In Figures 3 and 4 we present a model called "Aptidogram" where it is possible to draw a"profile"according to the variables of the individual, as well as to observe the behavior of the variables in relation to the group of individuals of the same age and sex. The "Aptidogram" is suggested as a presentation format of an individual's results and their physical abilities in units of standard deviation. An advantage of using the Aptidogram, is the easy accessibility to the results obtained from an individual, at the moment of the evaluation. Thus, the specific requirements, that need to be improved (lower values), as well as potentiated (upper values), are more accessible for their determination.

Figure 1 shows an example of a real individual from the 14-year-old boy database. In the Aptidogram he presents a Z of 3 in the horizontal jump variable, demonstrating important lower limb pushing force; this can be considered a determinant of physical capacity for sports that demand impulsion.

In Figura 4, it is observed an individual with a z-score equal to seven forVO2Max. This means that this individual has an outstanding aerobic capacity, and that she could have an exceptional performance in sports that require this kind of skills.

Table 3 individuals identified with Z-score $\geq 2$ in the variables described. It is noteworthy that boys exhibited a greater proportion of individuals with higher values in flexibility and arm flexion, whereas in girls it was in the VO2Max, horizontal jump and height variables. In addition, both groups showed higher proportion of individuals with low heart rate (HR) in the Cafra test. Finally, body weight was proportional in both groups as well.

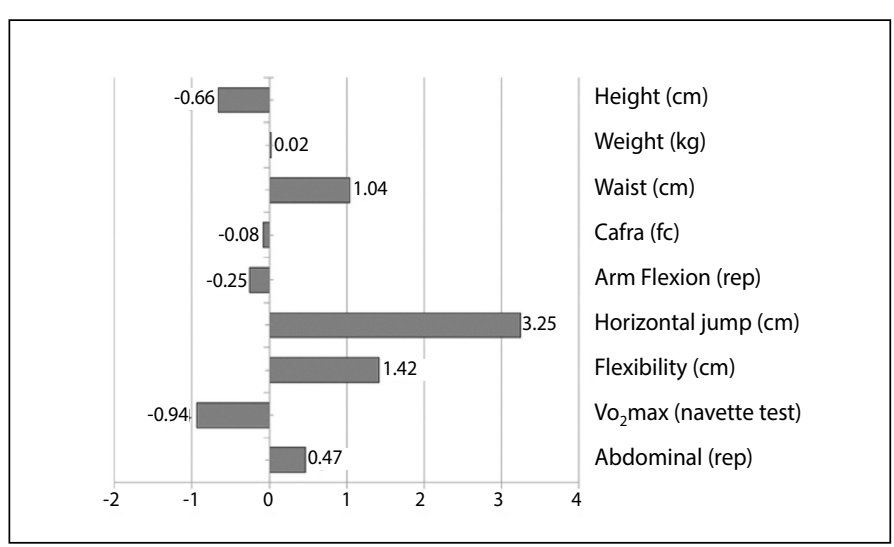

Figure 3. Aptidogram model based on data from a 14-year-old boy of the Chilean sample, 2013.

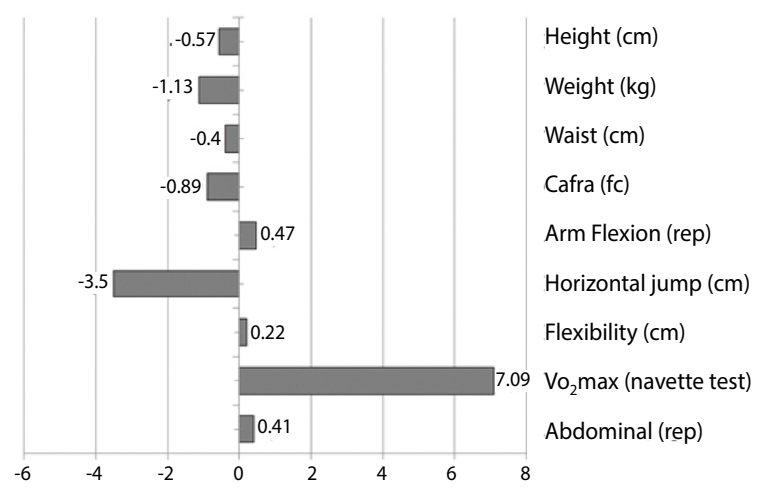

Figure 4. Aptidogram model based on the data of a 14-year-old girl from the Chilean sample, 2013. 
Table 3. Frequency and distribution according to age and sex of Chilean students with (Z>2) for each variable of physical and anthropometric capacity Chile, 2013.

\begin{tabular}{|c|c|c|c|c|}
\hline \multirow{2}{*}{$\begin{array}{c}\text { Variable } \\
\text { Total }\end{array}$} & \multicolumn{2}{|c|}{ Boy $\left(n^{\circ}=4802\right)$} & \multicolumn{2}{|c|}{$\operatorname{Girl}\left(n^{\circ}=4627\right)$} \\
\hline & $\mathrm{n}^{\circ}$ & $\%$ & $\mathrm{n}^{\circ}$ & $\%$ \\
\hline \multicolumn{5}{|c|}{ Z - Vo2max. } \\
\hline 13 & 26 & 0,28 & 20 & 0,22 \\
\hline 14 & 22 & 0,24 & 37 & 0,43 \\
\hline 15 & 1 & 0,01 & 6 & 0,06 \\
\hline 16 & 0 & 0,00 & 2 & 0,02 \\
\hline Total & 49 & 0,53 & 65 & 0,70 \\
\hline \multicolumn{5}{|c|}{ Z - Flexibility (cm) } \\
\hline 13 & 8 & 0,09 & 4 & 0,04 \\
\hline 14 & 11 & 0,12 & 2 & 0,02 \\
\hline 15 & 2 & 0,02 & 1 & 0,01 \\
\hline 16 & 1 & 0,01 & 0 & 0,00 \\
\hline Total & 22 & 0,24 & 5 & 0,05 \\
\hline \multicolumn{5}{|c|}{ Z - Horizontal Jump (cm.) } \\
\hline 13 & 12 & 0,13 & 30 & 0,32 \\
\hline 14 & 26 & 0,28 & 55 & 0,59 \\
\hline 15 & 7 & 0,08 & 7 & 0,08 \\
\hline 16 & 0 & 0,00 & 2 & 0,02 \\
\hline Total & 45 & 0,49 & 94 & 1,02 \\
\hline \multicolumn{5}{|c|}{ Z - Arm flexion (rep) } \\
\hline 13 & 50 & 0,54 & 44 & 0,48 \\
\hline 14 & 85 & 0,92 & 47 & 0,51 \\
\hline 15 & 21 & 0,23 & 10 & 0,12 \\
\hline 16 & 8 & 0,09 & 3 & 0,03 \\
\hline Total & 164 & 1,77 & 104 & 1,12 \\
\hline \multicolumn{5}{|c|}{ Z - Cafra (fc) } \\
\hline 13 & 22 & 0,24 & 29 & 0,31 \\
\hline 14 & 92 & 0,99 & 65 & 0,70 \\
\hline 15 & 17 & 0,18 & 13 & 0,14 \\
\hline 16 & 3 & 0,03 & 3 & 0,03 \\
\hline Total & 134 & 1,45 & 110 & 1,19 \\
\hline \multicolumn{5}{|c|}{ Z - Weight (kg.) } \\
\hline 13 & 36 & 0,39 & 40 & 0,43 \\
\hline 14 & 76 & 0,82 & 75 & 0,81 \\
\hline 15 & 15 & 0,16 & 14 & 0,15 \\
\hline 16 & 5 & 0,05 & 3 & 0,03 \\
\hline Total & 132 & 1,43 & 132 & 1,43 \\
\hline \multicolumn{5}{|c|}{ Z - Height (cm.) } \\
\hline 13 & 22 & 0,24 & 37 & 0,40 \\
\hline 14 & 40 & 0,43 & 52 & 0,56 \\
\hline 15 & 10 & 0,11 & 11 & 0,12 \\
\hline 16 & 1 & 0,01 & 3 & 0,03 \\
\hline Total & 73 & 0,79 & 103 & 1,11 \\
\hline
\end{tabular}

Vo2max is the only measure obtained by an indirect method.

\section{DISCUSSION}

Nowadays, the use of a systematic strategy to detect talents in Chilean population, has not been found in the literature. In this context, the objective of the present study was to identify physical and anthropometric characteristics above the mean population, considering age and sex of children and adolescents coursing $8^{\text {th }}$ grade of basic school. They were selected using the $Z$ strategy for the detection of sports talents, a methodology successfully performed in Brazil. ${ }^{15}$

Through the application of this method, it was possible to detect potential sports talents, that is, individuals with superior abilities in relation to biological aspects of, such as: anthropometric, metabolic and neuro-motor, both in boys and girls at different ages. ${ }^{16,17}$

The analysis of the data took into consideration the evaluation of a secondary database to obtain this result. The researchers did not have access to the relevant information such as how the data was included in the database, -- i.e., if the data was entered through a rigorous process to avoid typing errors--, which is considered a limitation in the present study. However, we emphasize that the evaluation of the quality of physical education has been carried out since 2010, being consider during the application of physical measures and tests in order to avoid errors in data collection.

The use of the $Z$ strategy to detect sporting talents was created by a Brazilian doctor and this model was featured in the Barcelona Olympics 1992 and later, it was published in the Encyclopedia of the International Olympic Committee as a national model for detecting sports talent. ${ }^{18}$

The use of SIMCE-EF for measuring the quality of physical education in schools can be considered a useful strategy, --not only to evaluate the effectiveness of school physical education, but also as an evaluation tool to assists in the search for new talents in sports of high performance at a national level--, by the identification of individuals with higher skills in the population. ${ }^{11}$

In this first analysis of the data, we did not identify individuals with values of abdominal strength highlighted at the national level. The possible explanation for this result can be explained by the method applied in the evaluation of this variable. Considering this method of abdominal strength evaluation, $80.8 \%(3,881)$ of the boy students and $60.2 \%(2,784)$ of the girl student's present excellent abdominal strength for their age. ${ }^{12}$

In other evaluation methods, for example, in the EUROFIT protocol widely used in Europe and Latin countries, abdominal strength is evaluated at maximum repetitions in 30 minutes, and they have a different classification according to each age and sex. ${ }^{19}$

In Brazil, the test protocol used in longitudinal studies in schoolchildren to measure abdominal strength, has different characteristics from those already presented, where the standardization suggests to perform the maximum of repetitions in 60 seconds. ${ }^{20}$

The present model was successfully applied in this sample, and is currently being processed to be widely applied, by the assessment of all the necessary factors and variables to cover the most relevant aspects, even now, a software for talent selection is being generated, which will be made available to sports coaches and teachers. ${ }^{21}$

The proposed model is far from being contemplated with all the necessary factors and variables covering all the necessary aspects. This study fulfilled three initial steps to generate a"Biological Model of Detection, Prescription and Prognosis" of future sports talents, which according to the Brazilian model are:

a. Performing physical fitness tests;

b. Generation of reference criteria and;

c. Strategy Z. For the next studies we suggest adding information from;

d. Functional maturation;

e. Biological maturation;

f. Nutritional status and;

g. Sports experience. 


\section{CONCLUSION}

The data indicate that in Chile there are children and adolescents with physical and anthropometric values above national standards for age and sex. In an early attempt to detect sport talents, the use of the Z strategy may be a tool capable of identifying performance standards that are ideal for high-performance sports. Finally, when searching for sport talents, besides the use of personalized strategies and perception of the professionals, it is important the proper use of systematic models based on science to attain the practical application of these models.

\section{ACKNOWLEDGMENTS}

The author thanks the Education Quality Agency for access to information.

All authors declare no potential conflict of interest related to this article

AUTHORS' CONTRIBUTIONS: Each author made significant individual contributions to this manuscript. JSL: contributed to the writing, revision and preparation of the entire research project; JLZ: contributed to data analysis and writing; RYS: contributed to the statistical analysis and revision; VKRM: analysis of the writing and revision; SMMM: contributed to the writing and revision and intellectual concept. All the authors approved the final version of the manuscript.

\section{REFERENCES}

1. Gabler H, RuoffBA. Zum problem der talentbestimmung im sport. Rahmentheoretisch voruberlegungen. Sportwissenschaft. 1979;9(2):164-80.

2. Vaeyens R, Lenoir M, Williams, AM, Philippaerts RM. Talent identification and development programmes in sport: current models and future directions. Sports Med. 2008;38(9):703-14.

3. Bohme MT. O tema talento esportivo na ciência do esporte. Rev Bras Ci e Mov. 2007;15(1):119-26.

4. Contreras LP. Detección de talentos deportivos en los clubes profesionales de fútbol de la región del Bío-Bío propuesta de un modelo de selección [Doctoral Dissertation]. Universidad de Concepción, 2011.

5. Ghorayeb N, Barros T. O exercício: preparação fisiológica, avaliação médica, aspectos especiais e preventivos. São Paulo: Atheneu 1999.

6. Instituto Nacional de Deporte (IND). Juegos deportivos escolares. Chile. [access in march 172017 ] Available in: http://www.ind.cl/deporte-competitivo/jde.

7. Bompa TO. Periodização: teoria e metodologia do treinamento. São Paulo: Phorte, 2002.

8. Weineck, J. Optimales training: leistungsphysiologische trainingslehre. Erlange, Perimed Fachbuch, 1990.

9. Weineck, J. Sportbiologie. Erlange, Perimed Fachbuch. 1992. p. 65-88

10. Carl K. Talentsuche, talentauswahl und talentförderung. Schorndorf: Hofmann-Verlag. 1988

11. Base de Datos de la Agencia de Calidad de la Educación. 2013. Santiago, Chile. [access in march 30, 2017]. Available in: http://www.agenciaeducacion.cl/evaluaciones/que-es-el-simce/.
12. Matsudo VK. Critérios biológicos para diagnóstico, prescrição e prognóstico de aptidão física em escolares de 7 a 18 anos de idade. [Tese]. Rio de Janeiro: Universidade Gama Filho; 1992.

13. Boyle M. Functional Training for Sports. Champaign, IL: Human Kinetics, 2010.

14. Bowers RW, Fox EL. Sports physiology. Wm C Brown Publishers, 1992.

15. Matsudo VK, Rivet RE, Pereira MH. Standard score assessment on physique and performance of Brazilian athletes in a six tiered competitive sports model. J Sports Sci 1987;5(1):49-53.

16. Gaya AC, Siva GM, Cardoso MF, Cardoso LT. Talento esportivo: estudo de indicadores somatomotores na seleção para o desporto de excelência. Rev Perfil. 2002;6(6):86-96.

17. Dias RM, Corrêa DA. Aspectos importantes no processo detecção e orientação de talentos esportivos e a contribuição da estatística Z neste contexto. Conexões. 2015;13(2):166-84.

18. Matsudo VK. Prediction of future athletic excellence. In: Bar-Or Oded (Ed.), The Child and adolescent athlete. Oxford: Blackwell Science. 1996. p. 92-109

19. Adam C, Klissouras V, Ravazollo M, Renson R, Tuxworth W, Kemper HC, et al. EUROFIT: European test of physical fitness. Rome: Council of Europe, Committee for the Development of Sport. 1988.

20. Matsudo VK. Testes em ciências do esporte. 7. ed. São Caetano do Sul: CELAFISCS, 2005.

21. Louzada F, Maiorano AC, Ara A. ISports: a web-oriented expert system for talent identification in soccer. Expert Syst Appl. 2016:44:400-12. 